\title{
THE EFFECT OF THE CASE OF COVID-19 ON SPORT ACTIVITIES OF THE VILLAGE OF SUKA NEGERI VILLAGE, LEBONG DISTRICT
}

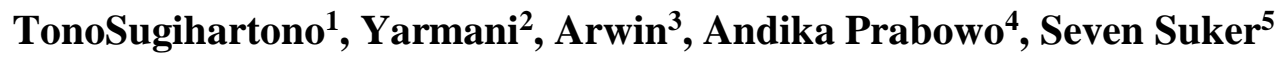 \\ ${ }^{123}$ Physical Education Study Program, FKIP, Bengkulu University, Bengkulu City, Indonesia
}

\section{Article Info}

HistoryArticles:

Received : March 2021

Revised : March 2021

Received: March 2021

Available online : March

2021

Keywords:

Covid-19 Case, Sports Activities

\begin{abstract}
This research aims to know the effect of the Covid-19 pandemic on sports activities of village residents of Suka Negeri at the age of 17-25 years. This research was conducted in Suka Negeri village in Lebong district. With this the type of research used is qualitative and the design used is a narrative design to describe the lives of individuals, collect and tell information about the lives of individuals, and report narrative about their experiences. The population in this study amounted to 60 people, the sampling in this study was carried out by purposive sampling technique, which is a sampling technique based on certain criteria or with certain judgments. The data collection technique in this study is to use a questionnaire. The questionnaire was used to obtain data about the effect of Covid 19 on sports activities among residents of the Village of Suka Negeri, Lebong Regency, ages 17 to 25 years. In the analysis of the questionnaire data, the calculation results obtained show that the number of residents who carry out sports activities with high intensity is 36 people or $60 \%$, while the number of residents who carry out sports activities with moderate intensity is 17 people or $28 \%$, while the number of residents who carry out activities low exercise is as much as 7 people or $12 \%$. Then the analysis of the questionnaire data shows that there is an influence of Covid 19 on sports activities in Suka Negeri Village residents, this can be seen from the number of Suka Negeri villagers who do the most sports activities, namely at very high intervals.
\end{abstract}




\section{INTRODUCTION}

The impact of the outbreak of the corona virus (Covid-19) has really been felt by the community. The Covid-19 virus pandemic has caused a very wide spread in countries around the world, including Indonesia. With that, many governments in the world temporarily stop activities outside the home such as work, school, vacation, and stop activities to gather in a crowd when outside the home.

According to the Task Force for the Acceleration of Handling the Covid 19 outbreak, in Indonesia itself, corona positive sufferers continue to increase. With this increase in sufferers, it has had a greater negative effect on people's lives. Addressing the covid case requires time and various kinds of special handling by the government appropriately. This can be done by intensively socializing with the health office about the impact of the Covid-19 epidemic itself, both from various aspects of prevention so how to deal with it. The impact caused by the spread of Covid-19 is felt in various sectors of life. So that it can affect the lifestyle and habits of citizens in everyday life.

Sports is one of the activities that is usually done outside the home. However, during a pandemic, this cannot be done. Even though sports activities are positive activities that are very useful, especially in maintaining health during a pandemic like now. Because we really need a variety of things that can ward off various diseases and increase immunity.

The impact of the Covid-19 pandemic on the activities of residents who have been accustomed to doing sports activities outside the home, such as: jogging, soccer, futsal, volleyball, basketball and gymnastics, were forced to replace them with sports activities carried out at home. This shows that the Covid-19 outbreak is affecting the sports activities of the citizens. Therefore, as a researcher I am very interested in being able to conduct research on how covid19 affects citizen sports activities. This research is based on the situation faced by residents today with the pandemic so that they can only do sports activities at home. The villagers of Suka Negeri before the Covid 19 pandemic used to do sports outside their homes. For example, by cycling or jogging around the village area of Suka Negeri. However, since the Covid 19 pandemic hit, sports activities outside the home must be stopped automatically. Because of the influence on sports activities that are usually carried out by the people of Suka Negeri Village, because residents who used to do sports routines outside the home now have to get used to activities at home. If this activity takes place regularly, meaning that by staying at home but doing very little or not doing sports activities at all, it is feared that it will interfere with the health of residents, especially during the Covid 19 pandemic, where we have to maintain our stamina and body power. because residents who used to do sports routines outside the home now have to get used to activities in the house.

If this activity takes place regularly, meaning that by staying at home but doing very little or not doing sports activities at all, it is feared that it will interfere with the health of residents, especially during the Covid 19 pandemic, where we have to maintain our stamina and body power. because residents who used to do sports routines outside the home now have to get used to activities in the house. If this activity takes place regularly, meaning that by staying at home but doing very little or not doing sports activities at all, it is feared that it will interfere with the 
health of residents, especially during the Covid 19 pandemic, where we have to maintain our stamina and body power.

According to Lia Amalia (2020), what can prevent disease caused by the corona virus is by increasing the immune system or immune system. The way that can be done to increase the body's immunity by adopting a healthy lifestyle such as eating more vegetables and fruits, resting in sufficient time can maintain endurance. Meanwhile, according to Abdul Arif (2020), to increase immunity itself, namely by consuming 4 healthy nutritious foods 5 perfect food menus that are complete and contain nutrients needed by the body such as carbohydrates, protein, vitamins and minerals. Doing a form of physical exercise / regular exercise can increase endurance and relieve inflammation, exercise that is done regularly has a better effect on immunity than exercise that is only occasionally, and take the time to do exercise within 30 minutes every day or at least 3-4 times a week. Exercise time can be done in the morning or evening. When doing sports, sports should not be done excessively because it will result in the impact of immune suppression or interference with the body's immunity. This exercise that is done excessively depends on the strength or endurance of a particular person. Before doing sports training activities, you should consult with a medical doctor or with the trainer, especially for the first time. From the opinions of the above experts. Based on the description above, the researchers are very interested in conducting research on how Covid 19 affects sports activities in the community, especially residents of Suka Negeri Village, Lebog Regency. This research is based on the situation faced by residents today with the pandemic, so they have to learn and do activities from home, especially sports.
Given that not all residents are accustomed to doing activities from home, especially sports are not activities that are usually done at home, so it is possible that the longer this pandemic will have an indirect effect on health due to the lack of activities that do physical exercise in normal situations.

The objects in this study were residents of Suka Negeri Village, Lebong Regency, aged 17 to 25 years. The choice of research object is due to the ease of access in obtaining and collecting data to be used in this study. Based on the description above, in this study the author raises the title "The Influence of the Covid-19 Pandemic on Sports Activities of Village Residents of Suka Negeri, Lebong Regency, Ages 17 to 25 Years".

\section{METHOD}

This research is a qualitative research and the research design used is a narrative design to describe the lives of individuals, collect and tell formations about the lives of individuals, and report narrative about their experiences (Alsa, 2011: 52).

Data collection techniques in the form of distributing questionnaires or kets. Existing data will be processed and analyzed using predetermined indicators. The results of the analysis are then interpreted and discussed so that in the end the results of the research can be concluded and given suggestions on the problem.

The population in this study were residents of Suka Negeri Village, Lebong Regency, who were related to the covid-19 case study of sports activities. According to Sugiyono (2013: 116), the sample "is part of the number and characteristics of the population. The sample in this study were 60 people in Suka Negeri Village, Lebong 
Regency, aged 17-25 years. The sampling method in this study was carried out using purposive sampling technique, which is a sampling technique based on certain criteria or with certain judgments. "

The data collection method in this study is to use a questionnaire. The questionnaire was used to obtain data about the effect of Covid 19 on sports activities among residents of Desa Suka Negeri, Lebong Regency, aged 17 to 25 years. The indicators used in this study are using a scale of 1-5 in which the questionnaire statement is stated as SS, S, KS, TS, STS. The following is an explanation for the questionnaire analysis indicators in the study.

After the data is obtained based on the work of residents, namely determining the effect of the Covid-19 case on sports activities, the data is analyzed. To find out more about the effect of the Covid-19 case on citizen sports activities, then the researcher provides a questionnaire to residents or all selected samples then the results from the distribution of the questionnaires were analyzed based on the percentage.

\section{RESULTS}

Suka Negeri Village has an area of 5,000 ha, consisting of $60 \%$ plantation land, $10 \%$ rice fields and $15 \%$ peat land, scrub and barren land $\square 5 \%$ and the rest is for settlement (village monograph, 2009). The borders of Suka Negeri Village include the West area bordering Topos Village, the East area with Ajai Siang Village, the South area is directly adjacent to the TNKS area and the North area borders the Talang Baru II Village. Geographically, Suka Negeri Village is a supporting village for the Kerinci Seblat National Park (TNKS). The main livelihood of the population is the agricultural sector which is dominated by the plantation sub-sector, namely, as many as 1,433 people or $95 \%$ of which are divided into coffee planters $(70 \%)$, rice farmers $(10 \%)$ vegetable farmers $(10 \%)$, and the rest make a living as a source of income. carpenter / mason,

Tabel 1. Recapitulation of the Age of the Village Residents of Suka Negeri, Lebong Regency

\begin{tabular}{cc}
\hline Age of Citizen & amount \\
\hline $17-19$ years & 11 \\
\hline $20-21$ years & 19 \\
\hline $22-23$ years & 22 \\
\hline$>25$ years & 8 \\
\hline
\end{tabular}

In the table above, it can be seen that the number of residents aged 17-19 years is as many as 11 people, residents aged 20-21 years are 19 people, residents aged 22-23 years are 22 people and residents aged over 25 years are as many 8 people.

Tabel 2. Recapitulation of Respondent Gender

\begin{tabular}{cc}
\hline Gender of Citizen & amount \\
\hline Women & 11 \\
\hline Man & 49 \\
\hline
\end{tabular}

From the table above, it can be seen that the number of residents with female gender is 11 people and male gender is 49 people.

Tabel 3. Interval Table Answers of villagers like the Lebong district.

\begin{tabular}{ccc}
\hline Interval & $\begin{array}{c}\text { Sports } \\
\text { Activity } \\
\text { Indicator }\end{array}$ & $\begin{array}{c}\text { Number of } \\
\text { villagers }\end{array}$ \\
\hline 100 & Very high & 0 \\
\hline $80-99$ & High & 36 \\
\hline $60-79$ & Moderate & 17 \\
\hline $40-59$ & Low & 7 \\
\hline $10-39$ & Very low & 0 \\
\hline
\end{tabular}

Based on the answer interval of the villagers above, the indicator of sports activity is obtained, namely 100 , there is a very high indicator with the 
number of residents 0 interval 80-99 there is a high indicator with the number of residents 36 people, 60-79 interval there is a moderate indicator with the number of residents 17 people, 40-59 intervals are found. Low indicator with 7 residents, interval 10-39, there is a very low indicator with 0 residents.

Table 4. Recapitulation Answers of villagers like the country of Lebong district in Percentage

\begin{tabular}{ccc}
\hline Interval & $\begin{array}{c}\text { Sports } \\
\text { Activity } \\
\text { Indicator }\end{array}$ & $\begin{array}{c}\text { Total } \\
\text { percentage } \\
(\mathbf{\%})\end{array}$ \\
\hline 100 & Very high & 0 \\
\hline $80-99$ & High & 60 \\
\hline $60-79$ & Moderate & 28 \\
\hline $40-59$ & Low & 12 \\
\hline $10-39$ & Very low & 0 \\
\hline
\end{tabular}

In the recapitulation table, the answers of villagers like the country are 80-99 intervals with high indicators, the percentage is 60-79 with moderate indicators, the percentage is $28 \%, 40-59$ intervals, with low indicators, the number of percentages is $12 \%$ by calculating the percentage, namely in the example the number of villagers who have a high category, namely 36 people with a calculation of $36 \times 100 \%: 60=$ $60 \%$ and so on. If the summary of the residents' answers is made in a graphic it will look like

The results of the calculation show that the number of residents who do sports with high intensity is as many as 36 people or $60 \%$, while the number of people who do sports activities with moderate intensity is 17 people or $28 \%$ while the number of people who do sports activities with low intensity is as many as 7 people. or $12 \%$. While the number of residents who do sports activities with very high intensity does not exist, as well as the number of residents who do sports activities with very low intensity.

\section{DISCUSSION}

This research has a type of narrative research which is to find out whether the effect of the Covid-19 case on the sports activities of the people of Suka Negeri Village, Lebong Regency, ages 17 to 25 years. This research was conducted for 1 month, during the research process the residents were given a questionnaire or questionnaire.

According to the results of research conducted on residents of Suka Negeri Village with cases of covid-19 on sports activities aged 17 to 25 years (table of intervals of residents 'answers and table of recapitulation of village residents' answers in percentage) according to these data it can be seen that residents who carry out activities sports with high intensity as many as 36 people with a percentage calculation of $60 \%$, including 15 people doing activities such as gardening with an average distance of approximately 8,770 $\mathrm{km} / 150$ minutes (2:30 hours), residents doing running sports (jogging) as many as 7 people, residents doing cycling sports as many as 8 people, residents doing weight lifting activities such as coffee and rice as many as 6 people

Based on the analysis above, it can be concluded that by providing questionnaires or questionnaires to residents so that they can find out how many people do sports activities during the pandemic and the effect of the Covid-19 case on sports activities.

\section{CONCLUSIONS}

From the results of data analysis and discussion, it can be concluded that the effect of Covid 19 on sports activities in Suka Negeri Village residents can be 
seen from the number of Suka Negeri villagers who do the most sports activities, namely at the "Very High" and "High" interval And "very low".

Residents doing sporting activities "High" during the Covid 19 Pandemic affected their health condition to carry out daily work activities. People did more "moderate" sports activities, so it can be concluded that the Covid 19 Pandemic had only a partial effect on sports activities. This is based on the assumption that only some residents do sports activities in maintaining passive health, especially during the Covid 19 pandemic. People are doing more "Very Low" sports activities, so it can be concluded that the Covid 19 Pandemic has no effect on sports activities. This is based on the assumption that residents do not consider it important to do sports activities in maintaining active health, especially during the Covid 19 pandemic.

Based on the description above, the results of the data analysis show that the number of people who do high sports activities is the highest, which is 36 people or $60 \%$, which means that it can be concluded that the Covid 19 pandemic affects the sports activities of the people of Suka Negeri Village for their age. 17 to 25 years. This is based on the assumption that residents maintain their health conditions so as not to be infected with the Covid 19 Virus.

\section{SUGGESTION}

This research has been carried out as closely as possible, but cannot be separated from the existing limitations, namely:

1. For villagers, always obey the prescribed health protocols, wear a mask, wash their hands and avoid gathering when outside the home.
2. It is better if the villagers should maintain sports activities, to maintain their immunity so that they are well maintained.

3. For researchers who want to continue this research in order to make this research as material for information and research with different populations or samples and in larger numbers.

\section{REFERENCES}

Abid Haleem, Mohd Javaid (2020).Effects of COVID-19 pandemic in daily life journal homepage: www.elsevier.com/locate/cmrp.

Adam B. Evans, Adam Et al, (2020).Sport in the face of the COVID-19 pandemic: towards an agenda for research in the sociology of sport. European Journal for Sport and Society, 17:2, 85-95, DOI: $10.1080 / 16138171.2020 .176$.

Alsa (2011). Religiusitas Penyandang Tunanetra. Jurnal pisikologi. Vol 5

Amelia, lia. (2020). Analisis Gejala Dan Peningkatan Kekebalan Tubuh Untuk Mencegah Penyakit Covid-19. Jurnal jambura. Vol 2.

Apituley, T. L., Pangemanan, D. H., \& Sapulete, I. M. (2021). Pengaruh Olahraga Terhadap Coronavirus Disease 2019. JURNAL BIOMEDIK: JBM, 13(1), 111-117.

Arif, Abdul. (2020). Tingkatan system imun untuk tangkis covid-19.

Arikunto, Suharsimi. (2010). Manajemen Penelitian. Jakarta: Rineka Cipta.

Fukuda, K. (2013). Emergence of novel coronavirus: global context. EMHJ, Vol. 19, Supplement 1.

Jauhari, M. N., Mambela, S., \& Zakiah, Z. (2020). Dampak Pandemi Covid-19 Terhapad Pelaksanaan Pembelajaran Penjas Adaptif Di Sekolah Luar Biasa. STAND: Journal Sports Teaching and Development, 1(1), 6370.

Karo, M. B. (2020, May). Perilaku Hidup Bersih dan Sehat (PHBS) Strategi 
Pencegahan Penyebaran Virus Covid19. In Prosiding Seminar Nasional Hardiknas (Vol. 1, pp. 1-4).

Maria, G. A. R., \& Nurwati, N. (2020). Analisis Pengaruh Peningkatan Jumlah Masyarakat Terkonformasi Covid-19 Terhadap Produktivitas Penduduk Yang Bekerja Di Jabodetabek. Focus: Jurnal Pekerjaan Sosial, 3(1), 1-15.

Nurhadi, J. (2020). Pengaruh Pandemi Covid-19 terhadap Tingkat Aktivitas Fisik pada Masyarakat Komplek Pratama, Kelurahan Medan Tembung. Jurnal Health Sains, 1(5), 294-298.

Purwanto, Ngalim, M.P,. (2011). PsikologiPendidikan, Bandung: PT Remaja Rosdakarya. Sugiyono.(2013).MetodePenelitianBis nis. Bandung: Alfabeta.

Susanto, N. (2020). Pengaruh Virus Covid 19 Terhadap Bidang Olahraga di Indonesia. Jurnal Stamina, 3(3), 145153.

Syahputra, A., Armayani, R. R., \& Syahmalluddin, L. S. (2020). Pengaruh Covid-19 Terhadap Aktivitas Sosial Dan Ekonomi Masyarakat Lhokseumawe. Etnoreflika: Jurnal Sosial Dan Budaya, 9(3), 226-237. 